\title{
APPLICATION OF MODERN MONITORING SYSTEMS IN MINI HYDROPOWER PLANTS
}

\author{
Nikola P. Žegarac \\ Serbian Academy of Inventors and Scientists, Belgrade, \\ Republic of Serbia \\ e-mail: zegaracnikola@vektor.net \\ ORCID iD: iohttp://orcid.org/0000-0002-1766-8184,
}

DOI: 10.5937/vojtehg64-9936

FIELD: energy, mechanical engineering, electronics ARTICLE TYPE: professional paper ARTICLE LANGUAGE: English

\begin{abstract}
:
The paper describes the application of modern monitoring systems in mini hydropower plants. Nowadays, special attention is paid to maintaining existing systems, as well as to the construction and installation of new mini hydropower plants. Mini hydropower plants are incorporated into power supply networks. They are very important for electricity production, as well as for the maintenance of power supply systems. New monitoring systems that allow continuous monitoring and supervision of technical correctness of mini hydropower plants have been implemented. Moreover, monitoring systems prevent damage to the system in case of major breakdowns and failures. Maintenance and overhaul are performed depending on real needs and technical conditions of hydropower plants. Modern equipment of renowned manufacturers, personal experience and knowledge of many co-workers have been used in this project realisation.
\end{abstract}

Key words: mini hydropower plants, modern monitoring systems, technical correctness, diagnostic parameters, diagnostic methods, system vibrations, devices, equipment.

\section{Introduction}

Modern monitoring systems in mechanical installations have a primary goal to timely react in order to prevent damage to mechanical assemblies or complete installations. Monitoring systems available on the market have broad applications: they can be used for internal combustion engines, hydroelectric power plants, thermal power plants, gas turbines, turbine systems in the process industry, reciprocating compressors, shipbuilding industry, cement factories, machine tools and for all other 
systems with installed slide and roller bearings, gears and other machine elements. The end user is offered a complete solution for monitoring mechanical systems without dismantling, and only in some installations partial disassembling is necessary in order to install a monitoring system (Žegarac, 1993). Monitoring systems allow fast and reliable measurement of the size of the gap in sliding and rolling bearings, measurement of vibration parameters and powerful vibration analyses as well as the measurement of speed, measurement of temperature of lubricating oils and coolants, lubricating oil analysis, and the positioning of the upper dead point in internal combustion engines. Since they are multichannel systems, a large number of diagnostic parameters can be monitored and measured.

The Electrical Industry Montenegro (EPCG) was offered two conceptions of monitoring systems (Žegarac, 2005a), (Žegarac, 2005b):

1. ON-line monitoring systems for continuous measurement and technical condition analyses. Measuring sensors (encoders) and measuring systems are installed into mechanical installations.

2. OFF-line monitoring systems are intended for periodic evaluation and analyses of the technical condition of machinery. Some sensors are permanently built into systems, depending on measured values, while other sensors are built into monitoring system portable parts for periodic measurements.

ON-line monitoring systems were chosen as a better solution.

\section{The concept and definition of mini hydropower plants}

Literature offers many definitions of small hydropower plants (SHPs). It is very difficult to find two countries with identical classification systems. The basic parameters that should be used in the classification of SHPs include (Žegarac, 2005b):

- Installed power of hydro units,

- Aggregate type in relation to the turbine, and the method of operation,

- Rpm (revolution per minute),

- Operation in relation to the overall energy system

- Installed head, etc.

Depending on turbine power, there are micro turbines (power up to $100 \mathrm{KW}$ ), mini turbine power systems up to $1 \mathrm{MW}$ and small or mediumsized turbines up to $10 \mathrm{MW}$. Also, regarding available power and head, there are the following SHPs types (Table 1). 
Table 1 - Types of mini hydropower plants

Таблица 1 - Виды мини-ГЭС

Tabela 1 - Vrste mini-hidroelektrana

\begin{tabular}{|c|c|c|c|c|}
\hline Type HPPs & Power $(\mathrm{KW})$ & Head $(\mathrm{m})$ small & Head $(\mathrm{m})$ middle & Head $(\mathrm{m})$ large \\
\hline Micro HPPs & do 50 & below 15 & $15-50$ & over 50 \\
\hline Mini HPPs & $50-500$ & below 20 & $20-100$ & over 100 \\
\hline Small HPPs & $500-5000$ & below 25 & & over 130 \\
\hline
\end{tabular}

The MHPs division according to available head is accepted in most countries which define equipment in accordance with the installed head. So, for example, a number of manufacturers of electro-mechanical equipment in the United States produce standardized aggregates that include a turbine, synchronous generator with an automatic control system, inlet valves, and a control panel for a maximum head of $15 \mathrm{~m}$ and a power of 10 to $5000 \mathrm{KW}$.

MHPs are further divided:

a) Depending on the procedure:

- Flow with side grip from the main watercourse

- With the reservoir-dam, with daily, weekly, annual or perennial smoothing,

b) Depending on the flow regulation:

- MHPs with adjustable flow control at the turbine inlet (manual or automatic control)

- MHPs with a constant flow rate, either because of the actual nature of the load or due to destruction of excess energy,

c) Depending on the network and operation mode:

- Isolated power plants - independent operation,

- Plants connected to the network-parallel operation,

- Power plants operating under the regime of on \pm , off \pm

- Plants with one, two or more units,

- Plants that operate if necessary, depending on consumption,

d) Depending on the installed capacity of hydropower:

- Pocket hydro electric power plants to $20 \mathrm{KW}$,

- Small HPPs from 0.5 to $1 \mathrm{MW}$,

- Small hydro power plants from 1 to $3 \mathrm{MW}$

- Medium HPPs from 3 to $10 \mathrm{MW}$,

- Large HPPs over 10 MW, 


\section{Advantages and disadvantages of MHPs}

The advantages of building MHPs in relation to the construction of other energy sources are numerous:

- Compared to large hydropower plants, there is neither flooding of wide areas (in order to provide space for water accumulation) nor disrupting of local ecological systems,

- They can provide land irrigation, water supply to surrounding villages, construction of ponds and flood protection,

- They reduce investments for electrification of remote settlements from the general electricity grid so that the electrification of these rural settlements can contribute to their development,

- They are exploited with very low material costs,

- Their operation life is very long, practically unlimited; the average life is 30 years, although there have been MHPs in operation for 80 years.

As energy sources, mini hydropower plants, compared to other similar sources, have drawbacks such as:

- High investment costs per installed KW,

- High research costs relative to total investment,

- Exploitation depends on existing resources,

- They require an integrated water supply system solution, where systems for water supply and irrigation have priority; therefore, MHPs must work with installed flow determined with respect to other consumers,

- If they operate autonomously, production of electric power depends on consumption, so the surplus remains unused.

\section{Design and implementation of modern monitoring systems in mini hydropower plants}

The requests to implement modern monitoring systems in mini hydropower plants within the Electrical Industry Montenegro (EPCG) were justified (Žegarac, Zuber, 2002, 2004, 2005).

An ON-line monitoring system was selected for the implementation(Žegarac, 2005).

The delivery and installation of the monitoring system equipment and devices were carried out by renowned international companies:

1. $01 \mathrm{~dB}$ - Metravib, a member of the AREVA corporation, Lyon, France - equipment and software for noise and vibration, 
2. Damalini AB, Sweden - laser alignment systems and laser geometric measurement systems,

3. Metrix USA, Low - cost systems for monitoring and protection of rotating systems,

4. CTC, USA - accelerometers and velocimeters with a lifetime warranty!

5. Guide InfraRed, China - thermal imaging cameras and monitoring systems,

6. VMI AB - Systems for dynamic balancing,

7. Technical Development Center (TRCpro) - Novi Sad, exclusive agent of the given companies.

\section{The system of the permanent monitoring of temperature and vibrations in the MHP Šavnik}

A modern monitoring system for two hydro units in the MHP Šavnik was designed. The hydro units are in the same room. The power of each aggregate is $100 \mathrm{KVA}$.

The monitoring system consists of:

-TRC PLC-based system,

- purpose-designed solution Areva 01dB-Metravib: MVX Oneprod in the eight-channel variant and Vio software.

The TRCpro PLC-based system for monitoring the state of turbines based on the RMS level of vibrations and temperature.

\section{Description of the system}

The system for protecting turbines from failure and damage is based on the measurement and monitoring of a large number of mechanical parameters of the plant. The measured and monitored values are the following ones:

- level of vibrations on the bearings (Vrms)

- temperature of the critical pump bearings,

- turbine speed,

- output electrical parameters of the generator.

These parameters directly or indirectly help in detecting irregularities in operation and in protecting plants from more possible errors. The protection system is designed to:

- prevent overheating of the turbine bearings and their damage,

- detect turbine rotor imbalance and prevent operation in conditions of high vibration levels. 
Table 2 - Configuration of the monitoring system of a mini hydropower plant

Таблица 2 - Конфигурация системы мониторинга мини-ГЭС

Tabela 2 - Konfiguracija monitoring sistema mini-hidroelektrane

\begin{tabular}{|c|c|c|}
\hline No & Pieces & Description \\
\hline 1. & 6 & $\begin{array}{l}\text { CTC } 200-1 \mathrm{R} \text {, one axial sensors for measuring the vibration level on the } \\
\text { bearings, Vrms, the range of } 65 \mathrm{~mm} / \mathrm{sec} \text {, loop powered } 4-20 \mathrm{~mA} \text { output }\end{array}$ \\
\hline 2. & 6 & PT100 sensors for measuring temperature of the bearings \\
\hline 3. & 1 & $\begin{array}{l}\text { Acquisition and control system TRC VZ-D, which consists of: } \\
\text {-CPU / PLC module } \\
\text { - Analog input units ( } 16 \text { channels) } \\
\text { - Digital input unit } 8 \times \text { IN } \\
\text { - Relay output unit } 4 \text { x OUT } \\
\text { - HMI panel } 5.7 \text { "color touch panel } \\
\text { - Purpose-designed firmware }\end{array}$ \\
\hline 4. & 1 & Communication GSM modem for sending an SMS alarm \\
\hline 5. & 1 & System installation, commissioning, operator training to work with systems \\
\hline
\end{tabular}

The Oneprod MVX protection system and Vio software for condition monitoring and turbine protection based on the RMS level of vibrations and temperature.

\section{Description of the designed system}

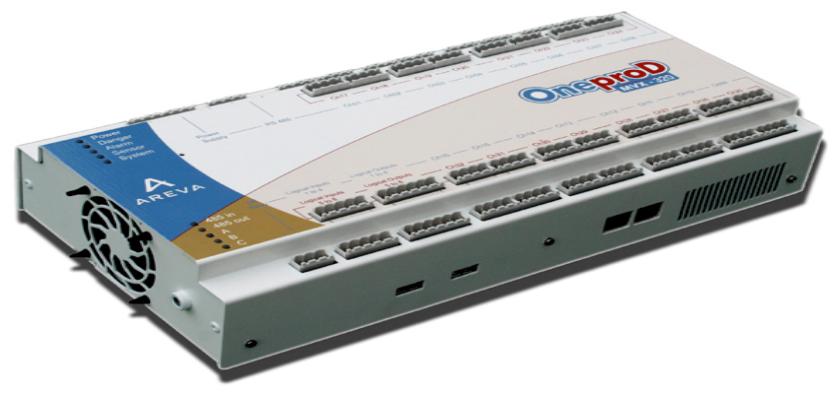

Figure 1 - Monitoring system OneproD - MVX

Puc. 1 - Системы мониторинга OneproD - MVX

Slika 1 - Monitoring sistem OneproD - MVX

The Oneprod-MVP is a modular monitoring system in 8, 16, 24 and 32-channel versions, shown in Fig. 1. Its superior possibility of simultaneous acquisition on all channels, combined with the programming of different operating modes and defining of alert thresholds for each operating mode make the system an extremely powerful solution for monitoring and on-line diagnostics of all complex rotating machines. 
The Oneprod-MVX allows acceptance of all types of vibration sensors (accelerometers, velocity sensors, proximity probes for monitoring relative vibrations in the hydrodynamic sliding bearings) as well as the process inputs. The Oneprod-MVX includes a large number of different onboard (analysis in the measuring system itself - neither download to a PC is required nor postprocessing calculations of vibration parameters) processing procedures applicable through various techniques of monitoring and technical diagnostics of rolling and sliding bearings: summary levels (RMS, Peak, Peak to Peak), narrowband parameters (Narrow Band), broadband parameters (Broad Band), Kurtosis parameter, Defect factor of bearings, Smax, frequency spectra, time records, zoomed spectra, and envelop spectra. The recorder module enables recording long signals for a subsequent analysis of the harmonic lines (recording turbine starting and deceleration) of the installed system (shown in Fig. 2).

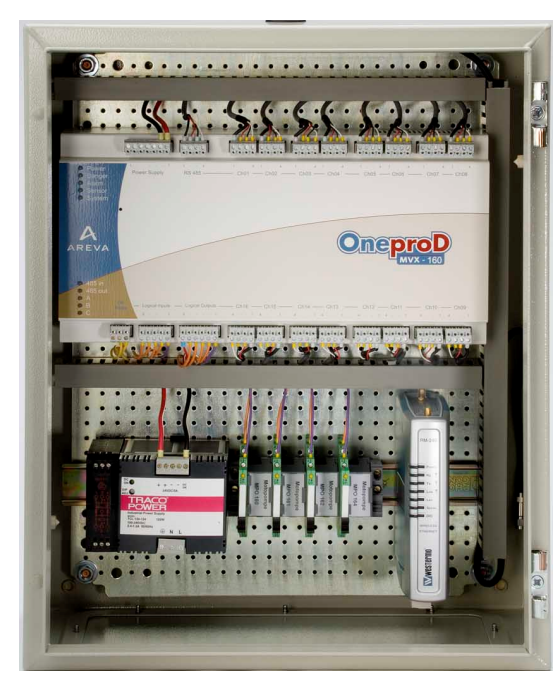

Figure 2 - Built-in monitoring system for the protection of mini hydropower plants Puc. 2 - Встроенная защитная система мониторинга для мини-ГЭС Slika 2 - Ugrađeni monitoring sistem za zaštitu mini-hidroelektrane

The configuration of the Oneprod-MVP system is performed on-site or remotely (from the control room or by using the Internet) using the included Oneprod CSM software. For realtime displays of all active channels and all defined parameters on channels, the Oneprod-MVX system uses Oneprod-XPR (Advanced vibro diagnostic) or Oneprod-VIO (Viewer) software. The communication of the Oneprod-MVX system with a control PC or PLC is carried out via RS485 or the Ethernet. 


\section{Options for extending the monitoring system}

After installing the Oneprod-MVX system, the existing turbine monitoring can be expanded by including the following measurement values (Table 3):

- Measurement of output electrical parameters of the generator,

- Turbine speed,

- Additional channels for measuring vibrations and temperature,

- Measurement of water flow to the turbine of the mini hydropower plant,

- Measurement and regulation of water flow at the hydropower plant dam - a new technical solution (Žegarac, 2004)

- Extension with advanced software and remote monitoring.

Table 3 - Expandable monitoring systems

Таблица 3 - Возможности расширения системы мониторинга Tabela 3 - Mogućnosti proširenja monitoring sistema

\begin{tabular}{|c|c|l|c|}
\hline No. & Code & \multicolumn{1}{|c|}{ Description } & Quantity \\
\hline 1. & MVX2301000 & $\begin{array}{l}\text { VIO-5, Viewer software for monitoring the results on a } \\
\text { computer }\end{array}$ & 1 \\
\hline 2. & AC102-1A & Industrial ICP accelerometer $100 \mathrm{mV} / \mathrm{g}$ & 4 \\
\hline 3. & CB102-A2A-030-Z & Special cable AC102-1A sensor, 6 meters & 4 \\
\hline 4. & MNTSTD & $1 / 4-28$ - M6: mounting stud & 4 \\
\hline 5. & SW & Terminal boxes & 2 \\
\hline 6. & PT & PT100 sensors for measuring temperature of bearings & 4 \\
\hline 7. & RCK & Industrial cabinet for MVX & 1 \\
\hline 8. & DOC & Documentation in English and Serbian language & 1 \\
\hline 9. & PC & PC computer & 1 \\
\hline 10. & INS & $\begin{array}{l}\text { System installation, commissioning, operator training to } \\
\text { work with systems }\end{array}$ & 1 \\
\hline
\end{tabular}


A joint monitoring system for two mini hydropower plants in the MHP Šavnik is given in Fig. 3 .

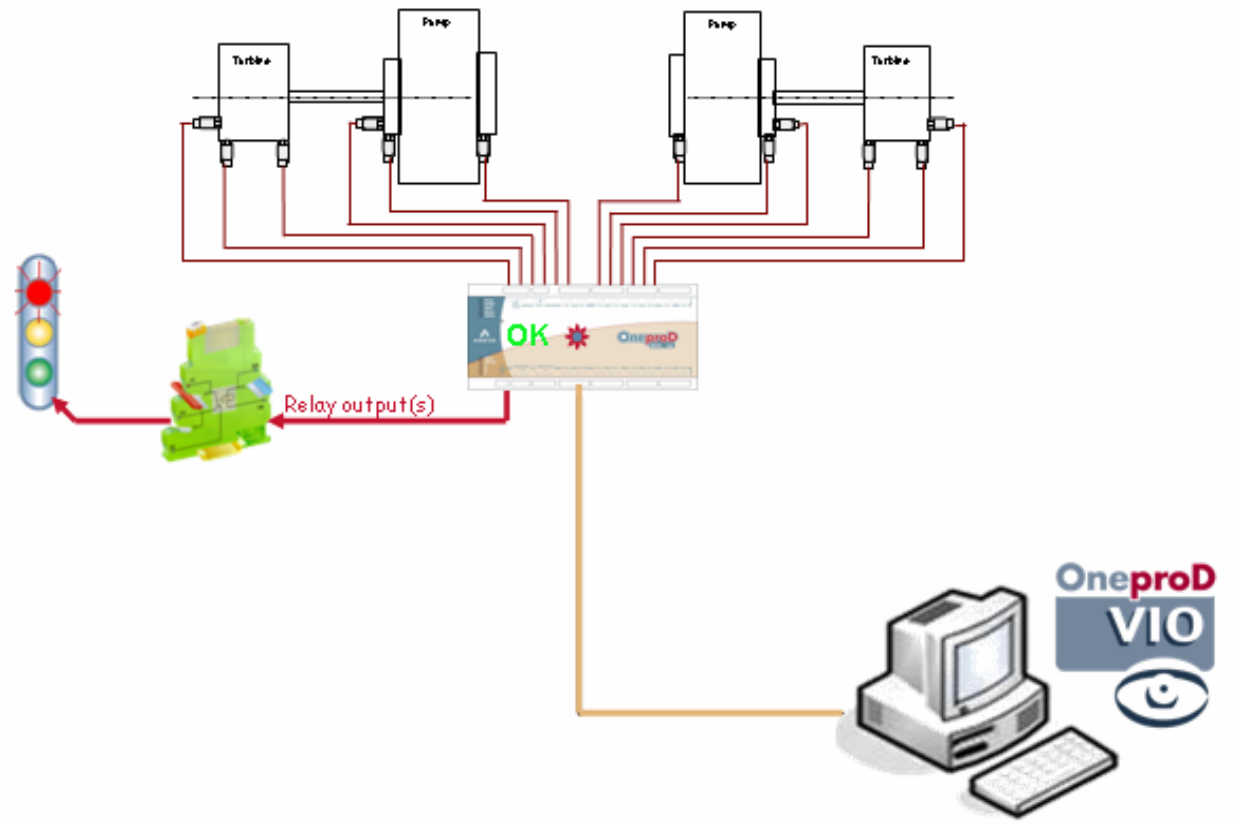

Figure 3 - The monitoring system for the mini hydropower plants in Šavnik

Puc. 3 - Система мониторинга на мини-ГЭС в Шавнике

Slika 3 - Monitoring sistem za mini-hidroelektrane u Šavniku

\section{Measurement results and their analysis}

Fig. 4 shows the scheme of the plant and the measuring points in one mini hydropower plant in the system of the EPCG Montenegro. The system consists of the mini hydroelectric generator $(A)$, momentum (B), the multiplier $(C)$, turbine $(D)$ and the turbine regulator $(E)$.

The assemblies are connected by flexible couplings and drive shafts.

\section{Labels for the measuring directions: $R H$ - horizontal,} $R V$ - vertical, $A X$ - axial

The designed monitoring system includes the measurement of vibrations, temperature, operating parameters and output electric parameters of the generator. The limit values of diagnostic parameters are selected and new and classical diagnostic methods are applied (Žegarac,1989). The monitoring system allows continuous monitoring and 
measurement of diagnostic values, extremely large memory of measured values as ell as wide possibilities of processing and analysing parameters.

The installation of devices and the equipment, final testing and commissioning of the operational work under the supervision of the designer were done by the TRCpro - Novi Sad.

Due to the volume of the measurement results, the paper shows only some values of the measured diagnostic parameters as well as the vibration parameters at characteristic measurement points (vibrations on the multiplier bearings).

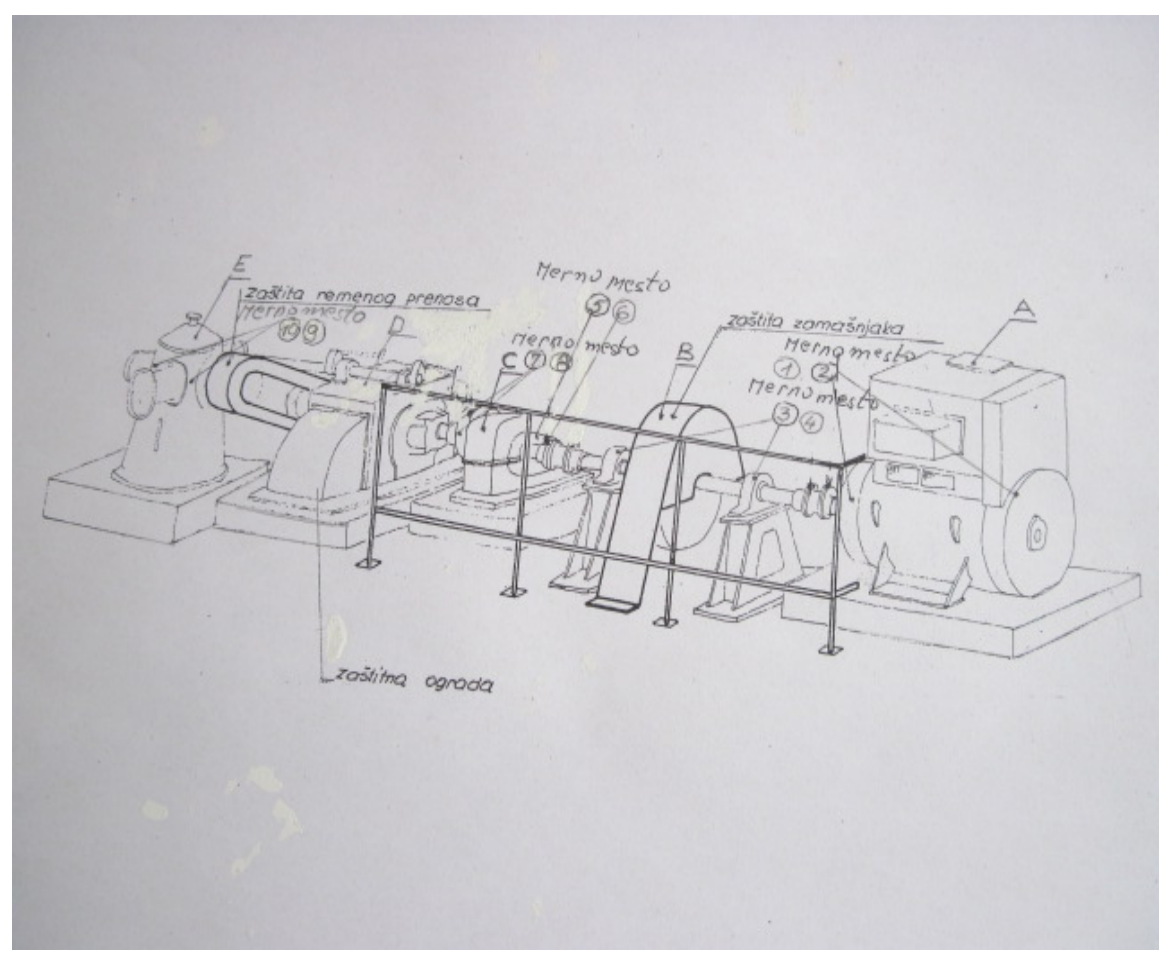

Figure 4 - Scheme of the plant and the measurement points at the mini hydropower plant Puc. 4 - Схема установки и точки замера на мини ГЭС

Slika 4 - Šema postrojenja i mernih mesta na postorjenju mini-hidroelektrane

In the spreadsheets, high levels of vibration parameters are displayed and marked in yellow and red.

Table 4 presents the measured values of the vibration parameters of measuring point 5 , the direction RV (bearing on the output shaft of the multiplier, on the side of the flywheel) while Table 5 shows the results for measuring point 7 , direction RV (bearing on the multiplier drive shaft on the side next to the turbine). 
Fig. 6 is a graphical display of the frequency spectrum at measuring point 5 , in the directions $\mathrm{RH}, \mathrm{RV}, \mathrm{AX}$, on the output shaft bearing, side to the flywheel, where high vibration levels can be noticed.

Table 4 - The measured values of vibration levels, measuring point 5, vertical direction-RV

Таблица 4 - Измеренные значения уровня шума, контрольная точка 5, направление $\mathrm{RV}$-по вертикали

Tabela 4 - Izmerene vrednosti nivoa vibracija, merno mesto 5, smer RV - vertikalno

\section{SECTOR DEMOIMACHINE AREAIHE}

\section{MHE}

FO - Mass unbalance

H2 - Misalignment

H3 - Misalignment

LF - $2 / 200 \mathrm{~Hz}$

$\mathrm{MF}-200 / 2000 \mathrm{~Hz}$
$\mathrm{HF}-2000 / 20000 \mathrm{~Hz}$

$\mathrm{HF}-2000$
$\mathrm{DEF}$

DEF
5AX

Acceleration - $2 / 20 \mathrm{kHz}$

Acceleration $-2 / 20 \mathrm{KHz}$

FO - Mass unbalance

H2 - Misalignment

$\mathrm{H} 3$ - Misalignment

LF $-2 / 200 \mathrm{~Hz}$

$M F-200 / 2000 \mathrm{~Hz}$
$\mathrm{HF}-2000 / 20000 \mathrm{~Hz}$

6RH

Acceleration - 2/20kHz

Velocity $-10 / 1000 \mathrm{~Hz}$

FO - Mass unbalance

H2 - Misalignment

$\mathrm{H} 3-$ Misalign
$\mathrm{LF}-2 / 200 \mathrm{~Hz}$

MF - 20012000

$\mathrm{MF}-200 / 2000 \mathrm{~Hz}$
$\mathrm{HF}-2000 / 20000 \mathrm{~Hz}$

DEF

DEF

Acceleration - $2 / 20 \mathrm{kHz}$

Velocity $-10 / 1000 \mathrm{~Hz}$

FO - Mass unbalance

H2 - Misalignment

H3 - Misalignment

LF $-2 / 200 \mathrm{~Hz}$

MF - $200 / 2000 \mathrm{~Hz}$

DEF

Acceleration - 2/20kH

Acceleration - 2/20khz

FO - Mass unbalance

H2 - Misalignment

H3 - Misalignmen

LF - $2 / 200 \mathrm{~Hz}$

MF $-200 / 2000 \mathrm{~Hz}$

HF - $2000 / 20000 \mathrm{~Hz}$

DEF
7RH

Acceleration - 2/20kHz

Velocity $-10 / 1000 \mathrm{~Hz}$

- Mass unbalance

H3 - Misalignment

$\mathrm{LF}-2 / 200 \mathrm{~Hz}$

MF $-200 / 2000 \mathrm{~Hz}$

HF - 2000/20000 Hz

DEF

Acceleration - $2 / 20 \mathrm{kHz}$

Velocity $-10 / 1000 \mathrm{~Hz}$

FO - Mass unbalance

H2 - Misalignment

H3 - Misalignment

LF - $2 / 200 \mathrm{~Hz}$

MF - $200 / 2000 \mathrm{~Hz}$
13/12/2006 12:15:38

\begin{tabular}{|c|c|c|c|c|c|c|c|c|c|c|}
\hline & Last Control & Value & & Ref. & Avg & Alm Type & $D G-$ & $A L-$ & $A L+$ & $D G+$ \\
\hline Soft & $13 / 12 / 2006 \quad 12: 15: 38$ & $0 \mathrm{~mm} \cdot \mathrm{s}-1$ & & 0 & & High & 0 & 0 & 4.3 & 11.2 \\
\hline Soft & $13 / 12 / 200612: 15: 38$ & $0 \mathrm{~g}$ & & 0 & & High & 0 & 0 & 2.1 & 5.6 \\
\hline Soft & $13 / 12 / 2006 \quad 12: 15: 38$ & $.001 \mathrm{~g}$ & & .001 & & High & 0 & 0 & 1 & 2.8 \\
\hline Soft & $13 / 12 / 2006 \quad 12: 15: 38$ & $.14 \mathrm{~g}$ & & .14 & & High & 0 & 0 & .3 & .6 \\
\hline Soft & $13 / 12 / 2006 \quad 12: 15: 38$ & $1.07 \mathrm{~g}$ & & 1.07 & & High & 0 & 0 & 1 & 2 \\
\hline Soft & $13 / 12 / 2006 \quad 12: 15: 38$ & $1.05 \mathrm{~g}$ & & 1.05 & & High & 0 & 0 & 3 & 5 \\
\hline Hard & $13 / 12 / 2006 \quad 12: 15: 38$ & $5.88 \mathrm{DEF}$ & & 5.88 & & High & 0 & 0 & 7 & 10 \\
\hline His & Last Control & Value Unit & $T-1$ & & Avg & Alm Type & $D G-$ & $A L-$ & $A L+$ & $5+$ \\
\hline Hard & $13 / 12 / 2006$ 12:15:38 & $2.62 \mathrm{~g}$ & & 2.62 & & High & 0 & 0 & 3 & 5 \\
\hline Hard & $13 / 12 / 2006 \quad 12: 15: 38$ & 7.95 mm.s- 1 & & 7.95 & & High & 0 & 0 & 4.3 & 11.2 \\
\hline Soft & $13 / 12 / 200612: 15: 38$ & $.031 \mathrm{~mm} . \mathrm{s}-1$ & & .031 & & High & 0 & 0 & 4.3 & 11.2 \\
\hline Soft & $13 / 12 / 2006$ 12:15:38 & $.0012 \mathrm{~g}$ & & .0012 & & High & 0 & 0 & 2.1 & 5.6 \\
\hline Soft & $13 / 12 / 2006 \quad 12: 15: 38$ & $.0023 \mathrm{~g}$ & & .0023 & & High & 0 & 0 & 1 & 2.8 \\
\hline Soft & $13 / 12 / 200612: 15: 38$ & $.424 \mathrm{~g}$ & & .424 & & High & 0 & 0 & .3 & .6 \\
\hline Soft & $13 / 12 / 2006$ 12:15:38 & $2.35 \mathrm{~g}$ & & 2.35 & & High & 0 & 0 & 1 & 2 \\
\hline Soft & $13 / 12 / 200612: 15: 38$ & $.965 \mathrm{~g}$ & & .965 & & High & 0 & 0 & 3 & 5 \\
\hline & $13 / 12 / 2006$ 12:15:38 & $5.77 \mathrm{DEF}$ & & 5.77 & & High & 0 & 0 & 7 & 10 \\
\hline
\end{tabular}

Hard 13/12/2006 12.15 38 (and

$13 / 1200612.15 .38 \quad 3.2 \mathrm{~g}$

13/12:2006 12:15.38 $\quad 4.18 \mathrm{~mm} . \mathrm{s}-1$

13/12/2006 12:15:38 $\quad .00037 \mathrm{~g}$

$13 / 12 / 2006$ 12:15:38 $\mathbf{. 0 0 1 6}$

13/22/2006 12:15:38 $\quad .189$

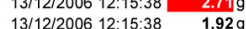

$13 / 12 / 2005$ 12.15.38 $7.79 \mathrm{DEF}$

13/12/2006 12:15:38 2.19 g

13/12/2006 12:15:38 $\quad \mathbf{3 . 7 2} \mathrm{mm} . \mathrm{s}-1$

13/12/2006 12:15:38 $\quad .026$ mm.s-

$13 / 12 / 2006$ 12:15:38 .000629

$13 / 12 / 2006$ 12:15:38 .00079

$13 / 12 / 2006$ 12:15:38 $\quad .111 \mathrm{~g}$

$13 / 12 / 200612.15 .38 \quad \mathbf{1 . 9 4}$

$13 / 12 / 200612.15 .38 \quad \mathbf{8 6 8} \mathrm{g}$

$13 / 1212000$ 12:15:38 $\quad 3.04$

\begin{tabular}{lll}
$13 / 12 / 2006$ & $12.15 \cdot 38$ & $3.04 \mathrm{~g}$ \\
\hline
\end{tabular}

$13 / 121200612.15 .38 \quad 8.54 \mathrm{~mm} . \mathrm{s}-1$

$13 / 12 / 200612 \cdot 15: 38$

$13 / 12 / 200612: 15: 38 \quad 0034$

$13 / 12 / 2006$ 12:15:38 $\quad .4239$

13/12/2006 12:15:38 2.78

$\begin{array}{lll}13 / 12 / 2006 & 12: 15: 38 & 1.19 \mathrm{~g}\end{array}$

Hard $13 / 12 / 200612: 15: 38$

$13 / 12 / 200612: 15: 38$

$13 / 12 / 2006$ 12:15:38

$13 / 12 / 2006$
$13 / 12 / 2006$
$12: 15: 38$

13/12/2006 12:15:38

13/12/2006 12:15:38

$\begin{array}{ll}13 / 12 / 12006 \\ 12.15: 38 & .196\end{array}$

$13 / 12 / 200612: 15: 38 \quad \mathbf{4 8 3}$

13/12/2006 12:15:38

$13 / 12 / 200612: 15: 38$

13/12/2006 12:15:3

$13 / 12 / 2006$ 12:15:38

$13 / 12 / 2006$ 12:15:38

$13 / 12 / 2006$ 12:15:38

13/12/2006 12:15:38

13/12/2006 12:15:38
$1.06 \mathrm{~g}$
$3.04 \mathrm{~mm} . \mathrm{s}-1$

$0 \mathrm{~mm} . \mathrm{s}-1$

$0 \mathrm{~g}$
$.0012 \mathrm{~g}$
$.129 \mathrm{~g}$
$.841 \mathrm{~g}$

$.129 \mathrm{~g}$

$.841 \mathrm{~g}$
$.495 \mathrm{~g}$
035

$\begin{array}{rr}4.3 & 11.2 \\ 4.3 & 11.2\end{array}$

4.311 .2

$\begin{array}{ll}0 & 1 \\ 0 & 3\end{array}$

$\begin{array}{rrr}0 & 3 & 5 \\ 0 & 4.3 & 11.2\end{array}$

2.311 .2

$\begin{array}{rrr}0 & 2.1 & 5.6 \\ 0 & 1 & 2.8\end{array}$

$\begin{array}{lll}0 & 3 & 6 \\ 0 & 3 & 5 \\ 0 & 7 & 10\end{array}$

35

$0 \quad 4.3 \quad 11.2$

$\begin{array}{rr}4.3 & 11.2 \\ 2.1 & 5.6\end{array}$

$\begin{array}{lll}0 & 1 \\ 0 & 3 & 28 \\ 0 & 1\end{array}$

$\begin{array}{lll}0 & 3 & \\ 0 & 3 & 5\end{array}$

33

$\begin{array}{lll}0 & 4.3 & 11.2 \\ 0 & 2.1 & 50\end{array}$

$\begin{array}{lll}0 & .3 & .6 \\ 0 & 1 & 2\end{array}$

$\begin{array}{rr}3 & 5 \\ 4.3 & 11.2\end{array}$

$4.3 \quad 11.2$

2.15 .6 
Table 5 - The measured values of vibration levels, measuring point 7 , vertical direction $-\mathrm{RV}$ Таблица 5 - Измеренные значения уровня шума, контрольная точка 7 , направление $\mathrm{RV}$-по вертикали

Tabela 5 - Izmerene vrednosti nivoa vibracija, merno mesto 7, smer RV - vertikalno

SECTOR DEMOIMACHINE AREAIHE

\section{MHE_}

7RV
DEF

7AX

Acceleration - $2 / 20 \mathrm{kHz}$

Velocity $-10 / 1000 \mathrm{~Hz}$

FO - Mass unbalance
H2 - Misalignment

H3 - Misalignment

LF $-2 / 200 \mathrm{~Hz}$

MF $-200 / 2000 \mathrm{~Hz}$

$\mathrm{HF}-2000 / 20000 \mathrm{~Hz}$

DEF

Acceleration $-2 / 20 \mathrm{kHz}$

Velocity - $10 / 1000 \mathrm{~Hz}$

FO - Mass unbalance

$\mathrm{H} 2$ - Misalignment

$\mathrm{H} 3$ - Misalignme

LF $-2 / 200 \mathrm{~Hz}$

MF $-200 / 2000 \mathrm{~Hz}$
$\mathrm{HF}-2000 / 20000 \mathrm{~Hz}$

DEF

Acceleration - 2/20kHz

FO-Mass unbalance

H2 - Misalignment

$\mathrm{H} 3$ - Misalignment

$\mathrm{LF}-2 / 200 \mathrm{~Hz}$

MF $-200 / 2000 \mathrm{~Hz}$

$\mathrm{HF}-2000 / 20000 \mathrm{~Hz}$

DEF
9RH

Acceleration - $2 / 20 \mathrm{kHz}$

Velocity - $10 / 1000 \mathrm{~Hz}$

H2 - Missalignment

H3 - Misalignment

LF - $2 / 200 \mathrm{~Hz}$

MF - $200 / 2000 \mathrm{~Hz}$

$\mathrm{HF}-2000 / 20000 \mathrm{~Hz}$

DEF

Acceleration - 2/20kHz

Velocity - $10 / 1000 \mathrm{~Hz}$

FO - Mass unbalance

$\mathrm{H} 2$ - Misalignment

$\mathrm{H} 3$ - Misalignme

LF - $2 / 200 \mathrm{~Hz}$

MF $-200 / 2000 \mathrm{~Hz}$
$\mathrm{HF}-2000 / 20000 \mathrm{~Hz}$

PAX

Acceleration - 2/20kHz

10RH

Acceleration - $2 / 20 \mathrm{kHz}$

Velocity - $10 / 1000 \mathrm{~Hz}$

FO - Mass unbalance

H2 - Misalignment

H3 - Misalignm

$\mathrm{F}-2 / 200 \mathrm{~Hz}$

MF $-200 / 2000 \mathrm{~Hz}$

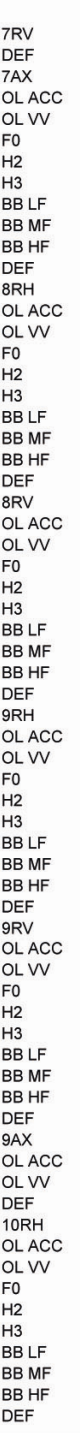

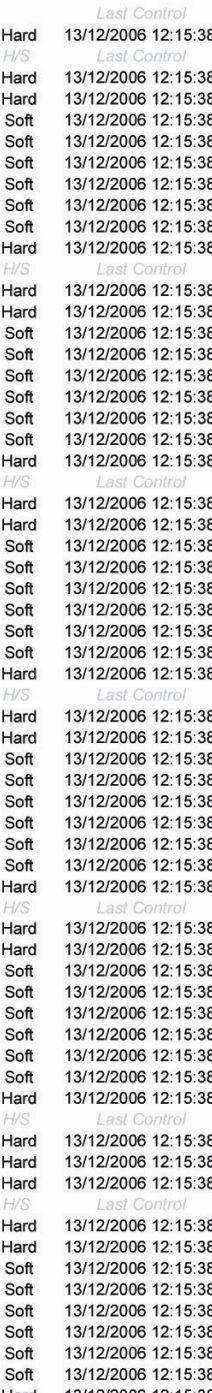

4.55 DEF

$2.83 \mathrm{~g}$
$8.44 \mathrm{~mm}$

$8.44 \mathrm{~mm} . \mathrm{s}-1$
$.01 \mathrm{~mm} . \mathrm{s}-1$

.00239

$0 \mathrm{~g}$
$.023 \mathrm{~g}$
$.363 \mathrm{~g}$

$.728 \mathrm{~g}$

$1.91 \mathrm{~g}$

$3.91 \mathrm{~mm} . \mathrm{s}-1$
$.016 \mathrm{~mm} . \mathrm{s}-1$

$0 \mathrm{~g}$
$0 \mathrm{~g}$
$172 \mathrm{~g}$

$1.57 \mathrm{~g}$

$.807 \mathrm{~g}$

$1.6 \mathrm{~g}$

$3.22 \mathrm{~mm} . \mathrm{s}-1$

$.025 \mathrm{~mm}$.

$0 \mathrm{~g}$
$.171 \mathrm{~g}$
$1.17 \mathrm{~g}$

$.171 \mathrm{~g}$
$1.17 \mathrm{~g}$

$1.23 \mathrm{~g}$

$1.55 \mathrm{~g}$

$1.16 \mathrm{~mm} . \mathrm{s}-1$
$.0037 \mathrm{~mm} . \mathrm{s}-1$

$\mathrm{Og}$

$0 \mathrm{~g}$
$.066 \mathrm{~g}$

$.066 \mathrm{~g}$
$.604 \mathrm{~g}$

$.604 \mathrm{~g}$
$1.28 \mathrm{~g}$

$1.28 \mathrm{~g}$
$3.92 \mathrm{DEF}$

$1.46 \mathrm{~g}$

$1.75 \mathrm{~mm} . \mathrm{s}-1$

$.025 \mathrm{~mm} . \mathrm{s}-1$

$.0003 \mathrm{~g}$

$.00026 \mathrm{~g}$

$.104 \mathrm{~g}$

$.456 \mathrm{~g}$
$1.5 \mathrm{~g}$

4.81 DEF

$.651 \mathrm{~g}$

$1.81 \mathrm{~mm} . \mathrm{s}-1$

3.05 DEF

13/12/2006 12:15:38

$1.26 \mathrm{~g}$
$1.12 \mathrm{~mm} . \mathrm{s}-1$
$0 \mathrm{~mm} . \mathrm{s}-1$

$0 \mathrm{~g}$

$0 \mathrm{~g}$

$.05 \mathrm{~g}$
$.187 \mathrm{~g}$

$1.1 \mathrm{~g}$
4.5 DEF

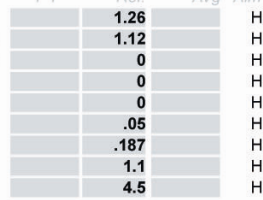




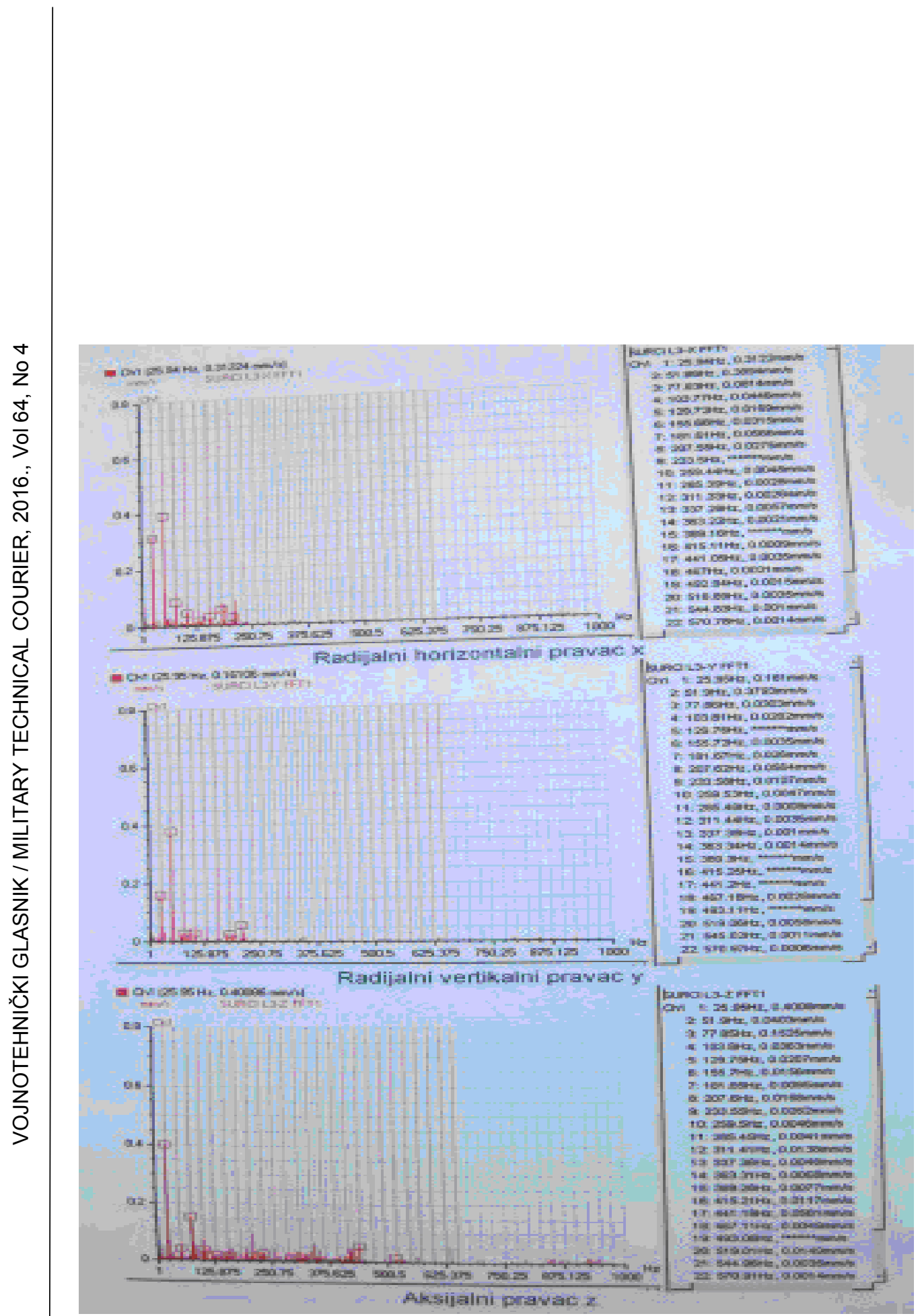

Figure 5 - Frequency spectrum of the measured vibrations and their analysis for bearing L5 Puc. 5 - Частотный спектр измеренных вибраций и их анализ на подшипнике L5 Slika 5 - Frekventni spektar izmerenih vibracija i njihova analiza za ležaj L5

Based on the measurement and the analysis of the measurement results, registered by the monitoring system, the following was determined: 
The general condition of both mini hydropower plants at the location Savnik, from the point of reference of ISO Standard 10816 and ISO Standard 2370, can be assessed as good or acceptable. On the flywheel bearings, points 3 and 4 , vibrations after reaching the operating temperature of the bearings are within acceptable limits. The levels of summary acceleration in the middle-frequency domain are elevated, but due to increased vibrations on the multiplier, they are further transmitted to the flywheel bearings. For the multiplier bearings, measuring points 5 and 6 (the output shaft) and measuring points 7 and 8 (the drive shaft), vibration levels are elevated as well as summary acceleration in the medium-frequency domain. Frequency spectra of vibrations on the multiplier bearings indicate the presence of problems in the gears, most likely due to their wear. For a definite confirmation of this claim, it is necessary to provide information on the number of teeth on the gears for a more precise diagnosis.

The monitoring system indicates that there is no need for balancing rotating masses (Žegarac, Ličen, Zuber, 1999); however, due to increased levels of vibrations on the multiplier, it is necessary to plan the overhaul of the mechanical assembly.

\section{Conclusion}

Nowadays, great attention is paid to the construction of new mini hydropower plants. The paper presents the application of a modern monitoring system on the mini hydropower plants in the system of the Electrical Industry Montenegro. Regardless of the fact that these systems were installed long time ago and that they have been in use for many years, it was fully justified to carry out the modernization of these mini hydropower plants. Mini hydropower plants have an important role in the production of electricity and are networked in the electricity system. The design and construction of mini hydroelectric power plants up to $700 \mathrm{KW}$ is very similar. These are hydro machines of horizontal construction and installation. In all assemblies of hydro units, there are built-in roller bearings. If power of mini hydropower plants exceeds the value of 1000 $\mathrm{KW}$, the construction of such systems is in a vertical version. Embedding assemblies in such hydropower plants is performed on sliding bearings. In this case, a patented system for the diagnostics of sliding bearings is applied as well as a new technical solution for measuring and controlling the flow of water at the hydropower dam. Modern monitoring systems presented in this work are fully applicable to the systems of mini hydropower plants of higher power. On the territory of the Republic of Serbia, there is a larger number of mini hydroelectric power plants in private ownership. It is expected that, in the near future, modern 
monitoring systems could be applied in them. The paper presents some examples of the application of modern monitoring systems. The function of controlling the technical correctness of such systems as well as of their overhaul is provided.The existing systems, installed in the 70 s, do not have a possibility of remote control. Malfunction alert is done by light or sound signaling - ALARM system. The MHP control system is of a manual type. A great advantage of modern monitoring systems is that operators in hydropower plants can react in time and prevent damage to the system in advance if they receive signals on major defects or failure occurrence.

\section{References}

Ličen, H., 2003. Vibrodijagnostika kao elemenat osiguranja kvaliteta i pouzdansoti. In: Naučno-stručni skup sa međunarodnim učešćem, Kvalitet, Zenica, B\&H.

Standard ISO 10816 Mechanical vibration of machines,1974.

Standard ISO 2370 Mechanical vibration of machines with operating speeds from 10 to $200 \mathrm{rev} / \mathrm{s}, 1974$.

Tehnička dokumentacija za Mini hidroelektrane, Crna Gora, 1974.

Žegarac, N., 1993.Postupak i uređaj za određivanje zazora u kliznim ležajevima, merenjem dinamičke putanje glavnih rukavaca kolenastog vratila motora sa unutrašnjim sagorevanjem.Beograd: Zavod za intelektualnu svojinu. Patent - br. 48216-P-640/93.

Žegarac, N., 2002, Izveštaj o merenju i analizi vibracija u MHE Kolašin.

Žegarac, N., 2005a, Projekat monitoring sistema za potrebe EPCG-MHE.

Žegarac, N. 2005b, Izveštaj o merenju i analizi vibracija MHE Lijeva Rijeka-C. Gora.

Žegarac, N., Zuber, N., 2004. Merenje i analiza vibracija u MHE Podgorica.

Žegarac, N., Zuber, N., 2005, Izveštaj o merenju i analizi vibracija na MHE Šavnik.

Žegarac, N., Ličen, H., Zuber, N., 1999, Izveštaj o merenju i analizi vibracija na elektroagregatima tipa No-break, snage 100 KVA, u Radarskoj stanici, KovionaBeograd.Beograd.

ПРИМЕНЕНИЕ СОВРЕМЕННЫХ СИСТЕМ МОНИТОРИНГА НА МИНИ-ГЭС

Никола П. Жегарац

Сербская академия изобретателей и ученых, Белград, Республика Сербия

ОБЛАСТЬ: машиностроение, электротехника, электроника

ВИД СТАТЬИ: профессиональная статья

ЯЗЫК СТАТЬИ: английский

Резюме:

В данной работе представлены современные системы мониторинга на мини-ГЭС. В современном мире особое внимание уделяется, как сохранению существующих систем, так и строительству и сооружению новых мини-ГЭС. Мини 
гидроэлектростанции входят в состав общей системы электроснабжения. Они играют важную роль в производстве электроэнергии, а также в поддержке общей системы энергопитания. В иелях постоянного бесперебойного наблюдения и технического надзора за работой мини-ГЭС разработаны новые системы мониторинга. Кроме основной функции наблюдения, они также предназначены для предотвращения аварий, в случае сбоя и отказов системы. Поддержка и ремонт системы производятся по необходимости, в зависимости от технического состояния гидроэлектростанций. B осуществлении данного проекта применены современное оборудование от известных мировых производителей, а также профрессиональный опыт и знания многих сотрудников.

Ключевые слова: мини гидроэлектростанции, современные системы мониторинга, техническое соответствие, параметры диагностики, методы диагностики, вибрации системы, приборы, оборудование.

PRIMENA SAVREMENIH MONITORING SISTEMA NA MINIHIDROELEKTRANAMA

Nikola P. Žegarac

Srpska akademija izumitelja i naučnika, Beograd, Republika Srbija

OBLAST: mašinstvo, elektrotehnika, elektronika

VRSTA ČLANKA: stručni članak

JEZIK ČLANKA: engleski

\section{Sažetak:}

$U$ radu je prikazana primena savremenih monitoring sistema na minihidrolektranama. U današnje vreme posebna pažnja posvećuje se održavanju postojećih sistema, izgradnji i instaliranju novih mini- hidrolektrana. One su umrežene u zajednički sistem napajanja električnom energijom $i$ veoma su značajne za proizvodnju električne energije, kao i za održavanje celokupnog sistema energetskog napajanja. Primenjeni su novi monitoring sistemi koji omogućavaju kontinualno praćenje i nadzor tehničke ispravnosti mini-hidroelektrana. Pored toga, monitoring sistemi omogućavaju da se spreče havarije sistema u slučaju većih kvarova i otkaza. Održavanje i remonti sistema vrše se zavisno od stvarne potrebe i tehničkog stanja hidroelektrana. Korišćena je savremena oprema renomiranih svetskih proizvođača, lično iskustvo i znanje mnogih saradnika na realizaciji ovog projekta.

Ključne reči: mini-hidroelektrane, savremeni monitoring sistemi, tehnička ispravnost, dijagnostički parametri, dijagnostičke metode, vibracije sistema, uređaji, oprema. 
Paper received on / Дата получения работы / Datum prijema članka: 06. 01. 2016. Manuscript corrections submitted on / Дата получения исправленной версии работы / Datum dostavljanja ispravki rukopisa: 27. 03. 2016.

Paper accepted for publishing on / Дата окончательного согласования работы / Datum konačnog prihvatanja članka za objavljivanje: 28. 03. 2016.

(C) 2016 The Author. Published by Vojnotehnički glasnik / Military Technical Courier (www.vtg.mod.gov.rs, втг.мо.упр.срб). This article is an open access article distributed under the terms and conditions of the Creative Commons Attribution license (http://creativecommons.org/licenses/by/3.0/rs/).

(c) 2016 Автор. Опубликовано в "Военно-технический вестник / Vojnotehnički glasnik / Military Technical Courier" (www.vtg.mod.gov.rs, втг.мо.упр.срб). Данная статья в открытом доступе и распространяется в соответствии с лицензией "Creative Commons"

(http://creativecommons.org/licenses/by/3.0/rs/).

(C) 2016 Autor. Objavio Vojnotehnički glasnik / Military Technical Courier (www.vtg.mod.gov.rs, втг.мо.упр.срб). Ovo je članak otvorenog pristupa i distribuira se u skladu sa Creative Commons licencom (http://creativecommons.org/licenses/by/3.0/rs/).

(c) (i) 